\title{
PENGARUH PENGAWASAN TERHADAP KINERJA KARYAWAN PADA PT.BUMI MENARA INTERNUSA DI LAMPUNG SELATAN
}

\author{
Yosita Oktavia $^{(1)}$, Ahiruddin $^{(2)}$, Trisnowati Josiah ${ }^{(3)}$ \\ Fakultas Ekonomi Universitas Sang Bumi Ruwa Jurai \\ yosita_oktavia@gmail.com,ahiruddin@fe.saburai.ac.id,trisnowati.josiah@fe.saburai.ac.id
}

\begin{abstract}
Abstrak. Pengawasan merupakan proses pengamatan dari seluruh kegiatan organisasi guna lebih menjamin bahwa semua pekerjaan yang sedang dilakukan sesuai dengan rencana yang telah ditetapkan sebelumnya. Masih kurangnya pengawasan dari atasan pada PT.Bumi Menara Internusa di Lampung Selatan yang mengakibatkan kinerja karyawan menurun. Kinerja karyawan masih belum optimal, hal ini tercermin pada belum tercapainya target penjualan di setiap tahunnya. Tujuan dari penelitian ini adalah untuk mengetahui pengaruh pengawasan terhadap kinerja karyawan pada PT. Bumi Menara Internusa di Lampung Selatan. Penelitian ini menggunakan metode analisis kualitatif dan kuantitatif. Pengumpulan data penelitian menggunakan teknik populasi dari seluruh karyawan pada PT.Bumi Menara Internusa berjumlah 33 orang. Berdasarkan hasil analisis kuantitatif, persentase sumbangan pengaruh variabel independen pengawasan $(X)$ terhadap variabel dependen kinerja karyawan $(\mathrm{Y})$ sebesar $24,8 \%$ dan sisanya dipengaruhi faktor lain. Uji hipotesis parsial melalui uji $\mathrm{t}$ diperoleh nilai $\mathrm{t}$ hitung antara pengawasan terhadap kinerja karyawan sebesar $t_{\text {hitung }}=3,200>t_{\text {tabel }}$ 1,692. Dengan demikian berarti bahwa ada pengaruh pengawasan terhadap kinerja karyawan pada PT.Bumi Menara Internusa di Lampung Selatan.
\end{abstract}

Kata kunci: Karyawan, Kinerja, Parsial, Pengawasan.

\section{PENDAHULUAN}

Perkembangan teknologi dewasa ini khususnya pada sektor ekonomi, mempunyai peranan yang sangat penting karena kinerja dari seorang karyawan sebagai tenaga kerja akan mempengaruhi faktor yang lain. Menyadari bahwa manusia adalah faktor penentu yang sangat penting dan menjadi pusat perhatian dari setiap kegiatan operasionalnya maka setiap organisasi dituntut mengelola sumber daya manusia yang ada agar tujuan yang diharapkan dapat tercapai. Pada dasarnya, kemampuan berfikir dan kemampuan mental yang handal dalam bertindak merupakan potensi yang telah ada pada manusia.

Organisasi merupakan kesatuan sosial yang dikoordinasikan secara sadar dengan sebuah batasan yang relatif dapat diidentifikasikan, bekerja secara terus menerus untuk mencapai tujuan (Robbins,
2006). Akibat terjadinya interaksi dengan karakteristik masing-masing serta banyak kepentingan yang membentuk gaya hidup, pola perilaku, dan etika kerja, yang kesemuanya akan mencirikan kondisi suatu organisasi. Sehingga setiap individu dalam organisasi tidak lepas dari hakekat nilainilai budaya yang dianutnya, yang pada akhirnya akan bersinergi dengan perangkat organisasi, teknologi, system, strategi dan gaya hidup kepemimpinan. Sehingga pola interaksi sumber daya manusia dalam berorganisasi harus diseimbangkan dan diselaraskan agar organisasi dapat tetap eksis.

Pengawasan merupakan proses pengamatan dari seluruh kegiatan organisasi guna lebih menjamin bahwa semua pekerjaan yang sedang dilakukan sesuai dengan rencana yang telah ditetapkan sebelumnya (Siagian, 2007). Sedangkan menurut (Simbolon, 2004) pengawasan ialah suatu proses dimana 
pimpinan ingin mengetahui apakah hasil pelaksanaan pekerjaan yang dilakukan oleh bawahannya sesuai dengan rencana, perintah, tujuan, kebijakan yang telah ditentukan.

(Terry dan Leslie, 2005) mengemukakan bahwa, Pengawasan adalah proses mengevaluasikan pelaksanaan kerja dengan membandingkan pelaksanaan aktual dengan apa yang diharapkan (goal and objectives) serta mengambil tindakan yang perlu. Dalam rangka meningkatkan disiplin kerja karyawan dengan tujuan untuk mencapai tujuan organisasi sangat perlu diadakan pengawasan, karena pengawasan mempunyai beberapa tujuan yang sangat berguna bagi pihak-pihak yang melaksanakan.

Menurut (Simanjuntak, 2011) kinerja adalah tingkat pencapaian hasil atas pelaksanaan tugas tertentu. Kinerja organisasi adalah tingkat pencapaian hasil dalam rangka mewujudkan tujuan organisasi. Manajemen kinerja adalah keseluruhan kegiatan yang dilakukan untuk meningkatkan kinerja organisasi, termasuk kinerja masing-masing individu dan kelompok kerja di organisasi tersebut. Kinerja individu, kinerja kelompok dan kinerja organisasi, dipengaruhi oleh banyak faktor intern dan ekstern organisasi.

Kinerja menurut (Robert L. Mathis dan John H. Jackson, 2006) adalah apa yang dilakukan atau tidak dilakukan oleh kita. Dari beberapa pendapat ahli dapat disimpulkan bahwa kinerja adalah hasil kerja yang dilakukan oleh seseorang dalam suatu organisasi agar tercapai tujuan yang diiginkan suatu organisasi dan meminimalisir kerugian. Dari beberapa pendapat ahli dapat disimpulkan bahwa kinerja adalah hasil kerja yang dilakukan oleh seseorang dalam suatu organisasi agar tercapai tujuan yang diiginkan suatu organisasi dan meminimalisir kerugian.

PT. Bumi Menara Internusa adalah salah satu perusahaan yang bergerak dibidang ekspor pengolahan hasil laut (seafood). Kondisi kinerja karyawan masih belum maksimal, dapat terlihat masih adanya karyawan yang kurang produktif hal ini disebabkan oleh kondisi kurangnya pengawasan dari pimpinan dan mengakibatnya menurunnya kinerja karyawan.

Target penjualan yang harus dicapai sebesar 4.500 ton setiap tahun nya, dan dapat terlihat bahwa perusahaan belum sepenuhnya mampu untuk mencapai target penjualan tersebut. Dengan demikian, perusahaan harus meningkatkan angka penjualan sesuai target setiap tahunnya dengan meningkatkan kinerja karyawannya.

Berdasarkan beberapa hal yang sudah disebutkan, penulis tertarik meneliti lebih lanjut dengan judul: "Pengaruh Pengawasan terhadap Kinerja Karyawan pada PT. Bumi Menara Internusa di Lampung Selatan".

\section{KAJIAN TEORI}

\section{Pengertian Pengawasan}

Pengawasan merupakan proses pengamatan dari seluruh kegiatan organisasi guna lebih menjamin bahwa semua pekerjaan yang sedang dilakukan sesuai dengan rencana yang telah ditetapkan sebelumnya (Siagian, 2007). Pengawasan mempunyai hubungan yang erat dengan fungsi manajemen lainnya, terutama dengan fungsi perencanaan. Pengawasan berhubungan dengan :

1. Perbandingan kejadian-kejadian dengan rencana-rencana

2. Melakukan tindakan-tindakan korektif yang perlu terhadap kejadian-kejadian yang menyimpang dari rencana-rencana.

Menurut (Herujito, 2006) Pengawasan (controlling) sebagai elemen atau fungsi keempat manajemen ialah mengamati dan 
mengalokasikan dengan tepat penyimpangan-penyimpangan yang terjadi.

(Terry dan Leslie, 2005) mengemukakan bahwa, Pengawasan adalah proses mengevaluasikan pelaksanaan kerja dengan membandingkan pelaksanaan aktual dengan apa yang diharapkan (goal and objectives) serta mengambil tindakan yang perlu. Sedangkan menurut (Simbolon, 2004) pengawasan ialah suatu proses dimana pimpinan ingin mengetahui apakah hasil pelaksanaan pekerjaan yang dilakukan oleh bawahannya sesuai dengan rencana, perintah, tujuan, kebijakan yang telah ditentukan.

\section{Tujuan Pengawasan}

Dalam rangka meningkatkan disiplin kerja pegawai dengan tujuan untuk mencapai tujuan organisasi sangat perlu diadakan pengawasan, karena pengawasan mempunyai beberapa tujuan yang sangat berguna bagi pihak-pihak yang melaksanakan.

Tujuan utama dari pengawasan ialah mengusahakan agar apa yang direncanakan menjadi kenyataan. Untuk dapat benarbenar merealisasi tujuan utama tersebut, maka pengawasan pada taraf pertama bertujuan agar pelaksanaan pekerjaan sesuai dengan instruksi yang telah dikeluarkan, dan untuk mengetahui kelemahan-kelemahan serta kesulitankesulitan yang dihadapi dalam pelaksanaan rencana berdasarkan penemuan-penemuan tersebut dapat diambil tindakan untuk memperbaikinya, baik pada waktu itu maupun waktu-waktu yang akan datang. (Manullang, 2004).

Sedangkan Soekarno dalam Saydam (2003) mengemukakan tujuan pengawasan antara lain adalah :

1. Untuk mengetahui apakah suatu kegiatan sudah berjalan sesuai dengan rencana.
2. Untuk mengetahui apakah suatu kegiatan sudah sesuai dengan instruksi.

3. Untuk mengetahui apakah kegiatan telah berjalan efisien.

4. Untuk mengetahui kesulitan-kesulitan dan kelemahan-kelemahan dalam kegiatan.

5. Untuk mencari jalan keluar bila ada kesulitan, kelemahan atau kegagalan kearah perbaikan.

\section{Indikator Kinerja}

Anwar Prabu Mangkunegara (2009) mengemukakan bahwa indikator kinerja, yaitu :

1. Kualitas

Kualitas kerja adalah seberapa baik seorang karyawan mengerjakan apa yang seharusnya dikerjakan.

2. Kuantitas

Kuantitas kerja adalah seberapa lama seorang pegawai bekerja dalam satu harinya. Kuantitas kerja ini dapat dilihat dari kecepatan kerja setiap pegawai itu masing-masing.

3. Pelaksanaan tugas

Pelaksanaan Tugas adalah seberapa jauh karyawan mampu melakukan pekerjaannya dengan akurat atau tidak ada kesalahan.

4. Tanggung Jawab

Tanggung jawab terhadap pekerjaan adalah kesadaran akan kewajiban karyawan untuk melaksanakan pekerjaan yang diberikan perusahaan.

\section{Faktor yang Mempengaruhi Kinerja}

Tinggi rendahnya kinerja seorang karyawan tentunya ditentukan oleh faktorfaktor yang mempengaruhinya baik secara langsung ataupun tidak langsung. Anwar Prabu Mangkunegara (2009) menyatakan bahwa faktor yang mempengaruhi pencapaian kinerja adalah faktor kemampuan (ability) dan faktor motivasi 
(motivation). Sedangkan menurut Keith Davis dirumuskan bahwa faktor-faktor yang dapat mempengaruhi kinerja adalah (Mangkunegara, 2009) :

1. Faktor Kemampuan

Secara psikologis, kemampuan (Ability) karyawan terdiri dari kemampuan potensi (IQ) dan kemampuan reality (knowledge + Skill). Artinya, karyawan yang memiliki IQ rata-rata (IQ 110 - 120) dengan pendidikan yang memadai untuk jabatannya dan terampil dalam mengerjakan pekerjaannya sehari-hari, maka ia akan lebih mudah mencapai prestasi kerja yang diharapkan. Oleh karena itu, karyawan perlu ditempatkan pada pekerjaan yang sesuai dengan keahliannya (the right man on the right place, the right man on the right job).

2. Faktor Motivasi

Motivasi terbentuk dari sikap seorang karyawan dalam menghadapi situasi kerja. Motivasi merupakan kondisi yang menggerakkan diri karyawan yang terarah untuk mencapai tujuan organisasi (tujuan kerja).

Sikap mental merupakan kondisi mental yang mendorong diri karyawan untuk berusaha mencapai prestasi kerja secara maksimal. Sikap mental seorang pegawai harus sikap mental yang siap secara psikofisik (sikap secara mental, fisik, tujuan dan situasi). Artinya seorang karyawan harus siap mental, mampu secara fisik, memahami tujuan utama dan target kerja yang akan dicapai serta mampu memanfaatkan dan menciptakan situasi kerja.

\section{METODE PENELITIAN}

\section{Objek Penelitian}

Objek pada penelitain ini adalah PT.Bumi Menara Internusa di jalan Ir
Sutami Km12. Kecamatan Tanjung Bitang Kabupaten Lampung Selatan. Pelaksanaan penelitian dimulai pada bulan April 2017 sampai dengan bulan Agustus 2017.

\section{Metode dan Teknik Pengumpulan Data}

Dalam penelitian ini jenis data yang diperlakukan adalah :

a. Data Primer

Data primer merupakan data dasar yang akan diperoleh langsung tanpa perantara orang atau lembaga lain sebagai pihak ketiga. Data primer ini diperoleh dengan wawancara melalui responden dengan menggunakan daftar pertanyaan.

\section{b. Data Sekunder}

Data skunder merupakan data yang diperoleh melalui orang lain yang berhubungan dengan permasalahan yang dipecahkan. Data sekunder ini diperoleh melalui cara studi dokumenter yaitu mengumpulkan dan mempelajari brosurbrosur serta dokumen organisasi.

Langkah-langkah pengumpulan data yang penulis lakukan dengan mengadakan penelitian lapangan yaitu Penelitian yang dilakukan di PT.Bumi Menara Internusa, adapun teknik yang digunakan dalam pengumpulan data adalah dengan :

1. Observasi, yaitu mengadakan survey atau pengamatan langsung kelokasi penelitian.

2. Interview atau wawancara, yaitu mengadakan tanya jawab langsung dengan karyawan pada PT.Bumi Menara Internusa.

3. Dokumentasi, yaitu mengumpulkan dan mencatat dokumentasi yang relevan.

4. Kuisioner, yaitu membuat pertanyaan yang berhubungan dengan variabel penelitian. 


\section{Sampel dan Populasi}

Teknik sampel yang digunakan dalam penelitian ini adalah dengan menggunakan teknik Random Sampling, yaitu menentukan jumlah sampel secara acak, dengan jumlah populasi 130 orang. Besarnya jumlah sampel adalah dengan mengikuti pendapat (Zainal Mustafa, 2004) yaitu semakin besar sampel yang diambil semakin tinggi tingkat representatifnya terhadap populasi.

Menurut pendapat Suharsimi Arikunto (2010) bahwa jika anggota populasi lebih besar dari 100 maka dapat dilakukan metode sampling dengan mengambil sampel sebesar 10 sd $25 \%$ dari anggota populasi, tetapi jika anggota lebih kecil dari 100 sebaiknya menggunakan metode sensus dengan meneliti seluruh anggota. Dari dasar tersebut, $25 \%$ x $130=33$ orang responden sebagai sampel, mewakili seluruh sifat sifat dari 130 karyawan.

\section{Metode Analisis Data}

Analisis Kualitatif yaitu pemecahan permasalahan yang dilakukan dengan cara membandingkan antara teori dengan praktek yang dilakukan pada objek penelitian.

Analisis kuantitatif yaitu menganalisis dengan menggunakan angka - angka yang dihimpun dari data perusahaan yang berkaitan dengan permasalahan yang dihadapi perusahaan. Penelitian ini menggunakan rumus statistik koefisiensi korelasi product moment (Sudjana, 2011):

$$
r_{x y}=\frac{N \sum X_{i} Y-\left(\sum X_{i}\right)\left(\sum Y_{i}\right)}{\sqrt{\left\{N \sum X_{i}^{2}-\left(\sum X_{i}\right)^{2}\right\}\left\{N \sum Y_{i}^{2}-\left(\sum Y_{i}\right)^{2}\right\}}}
$$

Keterangan:

$\mathrm{r}_{\mathrm{xy}}=$ Koefisieni korelasi

$\mathrm{X}=$ Variabel kesejahteraan karyawan

$\mathrm{Y}=$ Variabel kinerja karyawan

$\mathrm{N}=$ Jumlah populasi.
Dalam analisis kuantitatif ini penulis menggunakan perhitungan dengan pendekatan rumus Regresi linier Sederhana, dimana formulanya sebagai berikut :

$$
Y=a+b X+e
$$

Keterangan :

$$
\begin{aligned}
\mathrm{Y} & =\text { Kinerja karyawan } \\
\mathrm{a} & =\text { Konstanta } \\
\mathrm{b} & =\text { Koefisien regresi }(\mathrm{X}) \\
\mathrm{X} & =\text { Pengawasan } \\
\mathrm{e} & =\text { error term }
\end{aligned}
$$

Untuk mengetahui besarnya pengaruh, penghitungan koefisien korelasi tersebut kemudian dilanjutkan dengan Rumus Koefisien Determinasi atau Koefisien Penentu (KP):

$$
K P=(r)^{2} x 100 \%
$$

Untuk menguji secara hipotesis secara parsial digunakan Uji t dengan rumus :

$$
t_{\text {hitung }}=\frac{r \sqrt{N-2}}{\sqrt{1-r^{2}}}
$$

Keterangan:

$$
\begin{aligned}
& \mathrm{t}_{\text {hitung }}=\text { Nilai } \mathrm{t} \\
& \mathrm{r}=\text { Koefisien Korelasi } \\
& \mathrm{N} \quad=\text { Jumlah responden }
\end{aligned}
$$

Kriteria pengambilan keputusan :

1. Dengan melihat nilai signifikan (sig) sebesar 5\%. Bila nilai signifikan (sig) < 0,05 maka Ha diterima dan Ho ditolak yang bermakna model layak digunakan dalam penelitian ini, dan sebaliknya apabila nilai signifikan (sig) $>0,05$ maka Ho diterima dan Ha ditolak yang bermakna model tidak layak digunakan.

2. Membandingkan nilai $\mathrm{t}$ hasil perhitungan dengan nilai $t$ menurut 
tabel. Bila $\mathrm{t}$ hitung > dari nilai $\mathrm{t}$ tabel, maka Ho ditolak dan Ha diterima.

\section{HASIL DAN PEMBAHASAN}

\section{Uji Validitas dan Uji Realibilitas}

Uji validitas dan reliabilitas digunakan untuk pengujian instrument penelitian. Uji validitas dilakukan dalam penelitian ini untuk mengetahui valid atau tidaknya pertanyaan-pertanyaan yang digunakan dan atau dapat tidaknya digunakan sebagai alat ukur penelitian. Uji Reliabilitas digunakan untuk mengetahui nilai alpha pada setiap variabel Pengawasan (X) dan Kinerja Karyawan (Y) artinya variabel ini dapat digunakan untuk penelitian jika dinyatakan reliabel bila nilai alphanya 0,344 , ini berarti bahwa alat ukur yang digunakan dalam penelitian ini memiliki kemampuan untuk memberikan hasil pengukuran yang konsisten dalam mengukur gejala yang ada.

\section{Analisis Kualitatif}

Data distribusi hasil tanggapan responden variabel Pengawasan (X) dan Kinerja karyawan (Y) secara keseluruhan ditunjukkan oleh Tabel 1.

Tabel 1. Distribusi Data Pengawasan (X) secara keseluruhan

\begin{tabular}{cccc}
\hline Skor & Kategori & Frekuensi & Persentase \\
\hline $41-50$ & $\begin{array}{c}\text { Sangat } \\
\text { Baik }\end{array}$ & 28 & $84,8 \%$ \\
$31-40$ & Baik & 5 & $15,2 \%$ \\
$21-30$ & Sedang & - & - \\
$11-20$ & Buruk & - & - \\
$0-10$ & Sangat & - & - \\
\hline & Buruk & & $100 \%$ \\
\hline
\end{tabular}

Dari 33 orang responden penelitian, Pengawasan (X) pada PT. Bumi Menara Internusa dalam kategori "sangat baik" ada 28 orang $(84,8 \%)$, yang menyatakan "baik" ada 5 orang $(15,2 \%)$, dan yang menyatakan "sedang", "buruk" dan "sangat buruk" tidak ada $(0 \%)$.

Tabel 2. Distribusi Data Kinerja Karyawan (Y) secara keseluruhan

\begin{tabular}{cccc}
\hline Skor & Kategori & Frekuensi & Persentase \\
\hline $41-50$ & $\begin{array}{c}\text { Sangat } \\
\text { Baik }\end{array}$ & 22 & $66,7 \%$ \\
$31-40$ & Baik & 11 & $33,3 \%$ \\
$21-30$ & Sedang & - & - \\
$11-20$ & Buruk & - & - \\
$0-10$ & Sangat & - & - \\
\hline & Buruk & & $100 \%$ \\
\hline
\end{tabular}

Dari 33 orang responden penelitian, Kinerja Karyawan (Y) PT. Bumi Menara Internusa dalam kategori "sangat baik" ada 22 orang $(66,7 \%)$, yang menyatakan "baik" ada 11 orang $(33,3 \%)$, dan yang menyatakan "sedang" "buruk" dan "sangat buruk" tidak ada (0\%).

Berdasarkan hasil jawaban responden diatas dapat dijelaskan bahwa secara umum lingkungan kerja dan produktivitas kerja karyawan pada PT. Bumi Menara Internusa dalam kondisi baik. Kecenderungan jawaban secara dominan menggambarkan kondisi yang baik ini tentunya bila semakin ditingkatkan akan mendorong kinerja yang tinggi pada PT. Bumi Menara Internusa.

\section{Analisis Kuantitatif}

Berdasarkan hasil perhitungan tingkat korelasi antara variabel diperoleh besarnya tingkat korelasi antara variabel Pengawasan 
(X) dengan variabel Kinerja Karyawan (Y) pada PT. Bumi Menara Internusa adalah sebesar 0,498. Jika dikonsultasikan dengan tabel Kriteria Pengukuran hubunga Koefisien Korelasi (Sudjana, 1999) maka tingkat korelasi pengawasan (X) dengan variabel kinerja (Y) pada PT. Bumi Menara Internusa dalam kategori korelasi "sedang" terletak pada $(0,41-0,70)$.

Berdasarkan perhitungan diperoleh Koefisien Determinasi (KD) Pengawasan $(\mathrm{X})$ terhadap Kinerja (Y) dengan rumus KP $=\mathrm{r}^{2} \times 100 \%$ yaitu $\mathrm{KP}=0,248 \times 100 \%=$ $24,8 \%$. Hal ini menunjukkan bahwa variabel Pengawasan (X) menjelaskan perubahan terhadap variabel Kinerja $(\mathrm{Y})$ sebesar 24,8\%, sedangkan sisanya dijelaskan oleh faktor lain yang tidak dikaji dalam penelitian ini.

Standard Error of Estimate adalah suatu ukuran banyaknya kesalahan model regresi dalam memprediksikan nilai X. Dari hasil regresi didapat nilai 4,324. Sementara besarnya pengaruh yang diberikan variabel (X) terhadap variabel Y ( $R$ Square) adalah sebesar 0,248 atau $24,8 \%$.

Berdasarkan hasil uji t didapat nilai $\mathrm{t}_{\text {hitung }}=3,200$. Apabila dibandingkan dengan $t_{\text {tabel }}$ pada taraf signifikan yaitu 1,692 , maka $t_{\text {hitung }}=3,200>t_{\text {tabel }}=1,692$ sehingga dapat disimpulkan bahwa variabel Pengawasan (X) berpengaruh terhadap Kinerja (Y). Berdasarkan kondisi tersebut, bentuk persamaan regresinya adalah $\mathrm{Y}=$ $19,081+0,512 X+e$.

Dari persamaan regresi diatas dapat dijelaskan bahwa dengan nilai koefisien pengawasan yang positif menunjukkan apabila pengawasan meningkat baik maka kinerja akan meningkat. Nilai koefisien pengawasan sebesar 0,512 menunjukkan apabila pengawasan meningkat sebesar 1 satuan maka kinerja juga akan meningkat sebesar 0,512 satuan.

Hasil penelitian menunjukkan bahwa pengawasan (X) pada PT. Bumi Menara Internusa dalam kategori cukup baik. Untuk perhitungan pengaruh variabel pengawasan pada tabel diatas diperoleh angka $\mathrm{R}^{2}(\mathrm{R}$ Square) sebesar 0,248 atau $24,8 \%$. Hal ini menunjukkan bahwa persentase sumbangan pengaruh variabel independen pengawasan (X) terhadap variabel dependen kinerja karyawan (Y) sebesar 24,8\% dan sisanya dipengaruhi faktor lain. Uji hipotesis parsial melalui uji $\mathrm{t}$ test diperoleh nilai $\mathrm{t}_{\text {hitung }}$ antara pengawasan terhadap kinerja karyawan sebesar 3,200 dan $t_{\text {hitung }}=3,200>t_{\text {tabel }}$ 1,692 .

Persamaan regresi pengawasan terhadap kinerja karyawan pada PT. Bumi Menara Internusa adalah sebesar $\mathrm{Y}=$ $19,081+0,512 X+e$, yang menunjukkan setiap kenaikan satu satuan dari variabel pengawasan akan diikuti oleh naiknya variabel kinerja karyawan pada PT. Bumi Menara Internusa sebesar 0,12 point. Secara ekonomi dapat terlihat bahwa pengawasan merupaka salah satu aspek penting dalam membangun kinerja yang baik, tanpa pengawasan perusahaan akan sulit untuk mendapatkan hasil kerja yang baik.

\section{KESIMPULAN DAN SARAN}

\section{Kesimpulan}

Berdasarkan analisis data diperoleh kesimpulan bahwa hasil penelitian menunjukkan pengawasan (X) pada PT. Bumi Menara Internusa dalam kategori cukup baik. Untuk perhitungan pengaruh variabel pengawasan pada tabel diatas diperoleh angka $\mathrm{R}^{2}$ ( $\mathrm{R}$ Square) sebesar 0,248 atau $24,8 \%$. Hal ini menunjukkan bahwa persentase sumbangan pengaruh variabel independen pengawasan (X) terhadap variabel dependen kinerja karyawan (Y) sebesar $24,8 \%$ dan sisanya dipengaruhi faktor lain. Uji hipotesis parsial melalui uji $t$ test diperoleh nilai $t$ hitung antara pengawasan terhadap kinerja karyawan sebesar 3,200 dan thitung $=3,200>t_{\text {tabel }}$ 1,692. Persamaan regresi pengawasan 
terhadap kinerja karyawan pada PT. Bumi Menara Internusa adalah sebesar $\mathrm{Y}=$ $19,081+0,512 \mathrm{X}+\mathrm{e}$, yang menunjukkan setiap kenaikan satu satuan dari variabel pengawasan akan diikuti oleh naiknya variabel kinerja karyawan pada PT. Bumi Menara Internusa sebesar 0,12 point. Secara ekonomi dapat terlihat bahwa pengawasan merupaka salah satu aspek penting dalam membangun kinerja yang baik, tanpa pengawasan perusahaan akan sulit untuk mendapatkan hasil kerja yang baik.

\section{Saran}

Adapun saran yang diajukan peneliti adalah sebagai berikut:

1. Hendaknya pimpinan dapat memberikan teguran langsung kepada karyawan yang melakukan kesalahan/penyimpangan, agar karyawan tersebut jera dan tidak melakukan kesalahan yang sama lagi.

2. Untuk meningkatkan kinerja karyawan, maka standar kerja dari perusahaan menjadi bahan evaluasi agar karyawan tau dan dapat mememnuhi target pencapaian perusahaan.

\section{DAFTAR PUSTAKA}

Arikunto, Suharsimi. 2010. Prosedur Penelitian : Suatu Pendekatan Praktik (edisi). Jakarta: Rineka Cipta.

Ghozali, Imam. 2009. Aplikasi Analisis Multivariate dengan Program SPSS. Ed Keempat. Semarang: UNDIP.

Mangkunegara, AA. Prabu. 2009. Manajemen Sumber Daya Manusia Perusahaan. Cetakan ke sembilan. Bandung: PT. Remaja Rosdakarya.
Mathis, Robert. L \& Jackson. H. 2006. Manajemen Sumber Daya Manusia, Edisi 10. Jakarta: Salemba Empat.

Saydam, Goutali. 2003. Manajemen Sumber Daya Manusia : Suatu Pendekatan Mikro. Jakarta: Djambaran.

Sedarmayanti. 2011. Manajemen Sumber Daya Manusia dan Manajemen PNS. Cetakan Kelima. Bandung: PT. Refika Aditama.

Simanjuntak, Payaman J. 2011. Manajemen \& Evaluasi Kinerja. Jakarta: Fakultas Ekonomi UI.

Simbolon, Maringan Masri. 2004. DasarDasar Administrasi dan Manajemen. Jakarta: Ghalia Indonesia.

Stephen P. Robbins. 2006. Manajemen Edisi-7, Jilid 1, Edisi Bahasa Indonesia. Jakarta: PT. Indeks.

Sugiyono. 2009. Metode Penelitian Kuantitatif, Kualitatif, dan $R \& D$. Bandung: Penerbit Alfabeta.

Terry, George R. Dan Rue, Leslie W. 2005. Dasar-Dasar Manajemen. Jakarta: Bumi Aksara.

Wibowo. 2010. Manajemen Kinerja. Edisi ketiga. Jakarta: Rajawali Pers.

Wursanto. 2002. Dasar-Dasar Ilmu Organisasi. Yogyakarta: Andi. 